\title{
Extracts of medicinal plants with natural deep eutectic solvents: enhanced antimicrobial activity and low genotoxicity
}

\author{
Tsvetinka Grozdanova', Boryana Trusheva', Kalina Alipieva', Milena Popova', Lyudmila Dimitrova², \\ Hristo Najdenski², Maya M. Zaharieva², Yana llieva², Bela Vasileva³, George Miloshev³, Milena Georgieva ${ }^{3}$ \\ and Vassya Bankova ${ }^{1 *}$ (D)
}

\begin{abstract}
Natural deep eutectic solvents (NADES) are a new alternative to toxic organic solvents. Their constituents are primary metabolites, non-toxic, biocompatible and sustainable. In this study four selected NADES were applied for the extraction of two medicinal plants: Sideritis scardica, and Plantago major as an alternative to water-alcohol mixtures, and the antimicrobial and genotoxic potential of the extracts were studied. The extraction efficiency was evaluated by measuring the extracted total phenolics, and total flavonoids. Best extraction results for total phenolics for the studied plants were obtained with choline chloride-glucose 5:2 plus 30\% water; but surprisingly these extracts were inactive against all tested microorganisms. Extracts with citric acid-1,2-propanediol 1:4 and choline chloride-glycerol 1:2 showed good activity against S. pyogenes, E. coli, S. aureus, and C. albicans. Low genotoxicity and cytotoxicity were observed for all four NADES and the extracts with antimicrobial activity. Our results confirm the potential of NADESs for extraction of bioactive constituents of medicinal plants and further suggest that NADES can improve the effects of bioactive extracts. Further studies are needed to clarify the influence of the studied NADES on the bioactivity of dissolved substances, and the possibility to use such extracts in the pharmaceutical and food industry.
\end{abstract}

Keywords: Green extraction, Natural deep eutectic solvents, Sideritis scardica, Plantago major, Antimicrobial activity, Genotoxicity

\section{Introduction}

One of the most important aims of green chemistry has been to find green solvents for extraction of bioactive compounds from natural sources in order to replace the currently used hazardous organic solvents. One of the eco-friendly alternatives are deep eutectic solvents (DES) and particularly the natural deep eutectic solvents (NADES). DES are mixtures of organic compounds that have melting points lower than those of the individual

\footnotetext{
*Correspondence: bankova@orgchm.bas.bg

${ }^{1}$ Institute of Organic Chemistry With Centre of Phytochemistry, Bulgarian Academy of Sciences, Acad. G. Bonchev Str., Bl. 9, 1113 Sofia, Bulgaria

Full list of author information is available at the end of the article
}

components of the mixture and are liquid at ambient temperature. In the case of NADES, the constituents of the eutectic mixture are natural compounds: primary metabolites, which are easily available, non-toxic, biocompatible and sustainable [1]. NADES have low vapor pressure, an advantage with respect to environmental and human health protection. This property, however, poses a serious problem to the recovery of the active ingredients from the extract. Recently, several studies have demonstrated that NADESs retained or even improved the biological activity of dissolved substances [2, 3]. Therefore, the NADES could function as an active ingredient, and the extract could be directly used as part of cosmetic or pharmaceutical formulations, bypassing the difficulties of

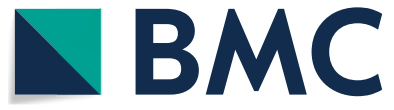

(c) The Author(s) 2020. This article is licensed under a Creative Commons Attribution 4.0 International License, which permits use, sharing, adaptation, distribution and reproduction in any medium or format, as long as you give appropriate credit to the original author(s) and the source, provide a link to the Creative Commons licence, and indicate if changes were made. The images or other third party material in this article are included in the article's Creative Commons licence, unless indicated otherwise in a credit line to the material. If material is not included in the article's Creative Commons licence and your intended use is not permitted by statutory regulation or exceeds the permitted use, you will need to obtain permission directly from the copyright holder. To view a copy of this licence, visit http://creativeco mmons.org/licenses/by/4.0/. The Creative Commons Public Domain Dedication waiver (http://creativecommons.org/publicdomain/ zero/1.0/) applies to the data made available in this article, unless otherwise stated in a credit line to the data. 
solute recovery. The aim of the present study was to apply selected NADES for extraction of two popular Bulgarian medicinal plants: the mountain tea Sideritis scardica Griesb., and the broadleaf plantain Plantago major L. as an alternative to water-alcohol mixtures, and to evaluate the antimicrobial, cytotoxic and genotoxic potential of both NADES solvents and extracts.

\section{Materials and methods}

\section{Chemicals and reagents}

Ethanol (absolute) was obtained from Alkaloid (Skopje, Macedonia). Glycerol and 1,2-propanediol were purchased from Valerus (Sofia, Bulgaria); choline chloride and Nile Red from Sigma Aldrich (Switzerland), citric acid and glucose from Chem-Lab NV (Zedelgem, Belgium) and Fisher Chemical (Loughborough, UK), respectively. The chemicals used in the in vitro cytotoxicity assay were purchased from Sigma ${ }^{\circledR}$ Life Science, (Steinheim, Germany): 3-(4,5-dimethylthiazolyl-2)-2,5diphenyltetrazolium bromide (MTT, \#M2128-1G), ethylenediaminetetraacetic acid (EDTA, \#E6635), L-glutamin (\#G7513) and Dulbecco's phosphate buffered saline (PBS, \#D8537). Media, enzymes and sera for cultivation CCL-1 cells originated from Capricorn ${ }^{\circledR}$, Germany: MEM (\#MEM-A), horse serum (\#HOS-1A), Pen/Strep 100x(\#PS-B), Trypsin (\#TRY-1B10, \#TRY2B10). $\mathrm{HCOOH}$ was delivered from Chimspektar OOD (Bulgaria).

\section{Plant material}

Aerial parts of the studied plants were used. Plantago major was collected in March 2018 in the valley of River

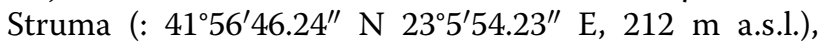
a voucher specimen (No. SOM 1390) has been deposited in the Herbarium of the Institute of Biodiversity and Ecosystem Research, Bulgarian Academy of Sciences (IBER-BAS). Sideritis scardica collected in June 2017, was cultivated in the Western Rhodope Mountain

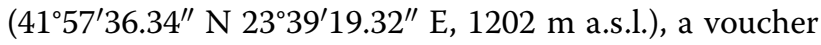
specimen has been deposited in the Herbarium of the IBER-BAS, No. SOM 1391. Plant material was collected and identified by Assoc. Prof. Dr. Ina Aneva.

\section{Preparation of NADES}

The NADES were prepared by mixing the components and subsequently stirring in water bath (300 rpm) combined with mild heating at $50{ }^{\circ} \mathrm{C}$ until a homogeneous liquid was formed [1].

\section{Polarity measurements}

The NADESs polarity was measured by the solvatochromic dye Nile red [4]. The dye was dissolved in each NADES in the concentration range $0.01-0.1 \mathrm{mM}$ and absorption spectra were recorded. The $\lambda_{\max }$ was used to calculate the molar transition energy ENR, based on the equation: $\mathrm{ENR}=\mathrm{hc}_{\mathrm{NA}} / \lambda_{\max }=28,591 / \lambda_{\max }$, (ENR in $\mathrm{kcal} /$ $\mathrm{mol}, \lambda_{\max }$ in $\mathrm{nm}$ ).

\section{Density measurements}

The NADESs density was determined as follows: $2 \mathrm{ml}$ of NADES were put in a volumetric flask at $20{ }^{\circ} \mathrm{C}$ and the weight of the liquid was measured. The density was calculated using the formula: $\rho=\mathrm{m}_{\text {NADES }} / \mathrm{V}_{\text {NADES }}$, where $\rho$ is density, $\mathrm{g} / \mathrm{ml}$ at $20{ }^{\circ} \mathrm{C}, \mathrm{m}_{\mathrm{NADES}}$ - weight, g at $20{ }^{\circ} \mathrm{C}$ and $\mathrm{V}_{\text {NADES }}$ - volume in $\mathrm{ml}$ at $20^{\circ} \mathrm{C}(2 \mathrm{ml})$. For each solvent the procedure was performed in duplicate.

\section{Extraction}

Air-dried plant material was ground using a coffee mill, the average particle size was $0.75 \mathrm{~mm}$. The extraction was performed in a $2 \mathrm{ml}$ Eppendorf tube with $50 \mathrm{mg}$ of plant material and $1.5 \mathrm{ml}$ solvent in an ultrasound bath (Elmasonic $\mathrm{S} 30 \mathrm{H}$ ), without heating, for $1 \mathrm{~h}$. The mixture was then centrifuged at 13,000 rpm for $40 \mathrm{~min}$ and filtered through cotton in a $1 \mathrm{ml}$ volumetric flask. This extract was further used for antimicrobial tests, and analyzed to determine the main groups of bioactive compounds in the extracts. Each extraction procedure was performed in triplicate.

\section{Quantitative determination of total phenolics and total flavonoids}

For measuring those two groups of bioactive compounds, previously reported spectrophotometric methods were used [5]. For blank: solution of respective NADES instead of the test sample was used in analogous procedures. Total phenolics content was estimated using caffeic acid as standard, and total flavonoid content with rutine as standard. Every assay was performed in triplicate.

\section{Antimicrobial activity Test microorganisms}

For antimicrobial activities of extracts and solvents, the following test-microorganisms were used: Bacillus cereus ATCC 9634 (American Type Cell Culture Collection, USA), Escherichia coli ATCC 35218, Staphylococcus aureus ATCC 29213, Pseudomonas aeruginosa ATCC 27853, Listeria monocytogenes C12, Salmonella typhimurium 123, Streptococcus pyogenes 10535, Yersinia enterocolitica 864 O:3 and the fungus Candida albicans 562 from the SAIM-BAS collection.

\section{Culture medium and growth conditions}

Sterilized Brain Heart Infusion Broth and Agar (BHIB, GM210, resp. BHIA, M1611, HiMedia, India) were used as the cultivation media for all bacteria excepting $S$. 
thyphimurium, S. aureus and E. coli growing on Muller Hinton Agar and Broth (MHA, CM0337B, resp. MHB, CM0405B, Thermo Scientific-Oxoid, UK), and C. albicans SAIMC 562-on Sabouraud-Glucose agar supplemented with gentamicin $(40 \mu \mathrm{g} / \mathrm{ml})$ (CM0041, Oxoid, Basingstoke, UK). All microorganisms were grown at $37^{\circ} \mathrm{C}$ overnight except $B$. cereus, which was cultivated at $30{ }^{\circ} \mathrm{C}$ and $Y$. enterocolitica - at $26^{\circ} \mathrm{C}$. All microbiological procedures were performed under sterile conditions into a Class II laminar box (FASTER BH-EN 2003, Ferarra, Italy).

\section{Minimal inhibitory (MIC) and bactericidal (MBC) concentrations}

The antimicrobial activity was studied by the broth microdilution method according to ISO 20776-1:2006. Briefly, bacterial and fungal inoculums with concentration $105 \mathrm{CFU} / \mathrm{ml}$ were added to 96 -well plates containing BHIB or MHB loaded with twofold serial dilutions of pure solvents or extracts differing in the concentration of total phenolics. Pure solvents were applied in an equivalent concentration as for testing the antimicrobial activity. Plates were incubated overnight at $37^{\circ} \mathrm{C}$, excepting the plates with $B$. cereus and $Y$. enterocolitica, which were incubated at $30{ }^{\circ} \mathrm{C}$, respectively $26^{\circ} \mathrm{C}$. Gentamicin, penicillin and tetracycline were used as reference antibiotics for bacteria and amphotericin B-for C. albicans, following the requirements of EUCAST. Experiments were performed in triplicate. MICs and MBCs were determined as described before [6].

\section{Dehydrogenase (DEHA) activity}

The DEHA activity of the test microorganisms was assessed by MTT-test (3-(4,5-dimethylthiazolyl-2)-2,5diphenyltetrazolium bromide, M2128-1G, SigmaAldrich). The method is based on the reduction of the MTT dye by the membrane located bacterial enzyme $\mathrm{NADH}$ : ubiquinone reductase (H+-translocation) to insoluble formazan crystals. Briefly, the treated and untreated bacterial, respectively fungal cells, were incubated for $2 \mathrm{~h}$ with MTT dye in a final concentration of $0.05 \mathrm{mg} / \mathrm{ml}$. An equivalent volume of $5 \% \mathrm{HCOOH}$ in isopropanol dissolved the formed crystals. Absorption was measured using ELISA reader (BioTek Elx800, USA) at $550 \mathrm{~nm}$ (reference $690 \mathrm{~nm}$ ) against a blank solution.

\section{In vitro cytotoxicity}

\section{Cell line and culture conditions}

The cell line CCL- ${ }^{\mathrm{TM}}$ (mouse fibroblasts, NCTC clone 929, ATCC-American Type Culture Collection, Manassas, Virginia, USA) recommended in Annex C of ISO 10993-5 (ISO 10993-5:2009 2017) for evaluation of in vitro cytotoxicity was cultured in sterile cell culture flasks and controlled environment (incubator Panasonic MCO-18AC, Japan) at $37^{\circ} \mathrm{C}, 5 \% \mathrm{CO}_{2}$ and approx. 95\% humidity. The cultivation medium MEM was supplemented with $2 \mathrm{mM}$ L-glutamine, 10\% heat-inactivated horse serum, $10^{5}$ Units/l penicillin $\mathrm{G}$ sodium and $100 \mathrm{mg} / \mathrm{l}$ streptomycin sulphate. Cells were sub-cultivated at a seeding density of $1 \times 10^{4}$ cells $/ \mathrm{cm}^{2} 1-3$ times per week after reaching $80-90 \%$ confluence. Sequentially, applied solutions of $0.05 \%$ EDTA in PBS $(1-2 \mathrm{ml}$, 5-10 $\mathrm{min})$ and $0.25 \%(\mathrm{w} / \mathrm{v}) / 0.53 \mathrm{mM}$ trypsin/EDTA (1-2 ml, 5-10 min) were used for the detachment of the cell monolayer and cell separation.

\section{MTT test-calculation of $I C_{50}$ and statistics}

The MTT test was conducted according to Annex C, ISO 10993-5 [7, 8]. Cells with a density of $1 \times 10^{5} \mathrm{ml}^{-1}$ were seeded in 96-well plates (flat bottom, $100 \mu \mathrm{l} /$ well). For cells to start exponential growth (log phase), plates were incubated for $24 \mathrm{~h}$. After entering the log phase cells were exposed to NADES and their extracts at concentrations ranging between 2 and $0.004 \%$ volume fraction for 24 and $72 \mathrm{~h}$. PBS was used as a solvent and 4 wells were used for each treatment. MTT $(0.5 \mathrm{mg} / \mathrm{ml}$ final concentration) was added to each well, followed by a 2 -h incubation at $37{ }^{\circ} \mathrm{C}$. The medium above the cells was removed and $100 \mu \mathrm{l} /$ well 2-propanol supplemented with $5 \%$ formic acid were used to dissolve the formed formazan crystals and as a blank solution. Absorption was measured at $540 \mathrm{~nm}$ (reference filter 690) on a microplate reader ELx800 (BioTek Instruments, Inc., United States). The $\mathrm{IC}_{50}$ values (inhibitory concentration 50 which reduces vital cells by half) were calculated with a non-linear regression analysis (inhibition dose-response model, variable slope) using the GraphPad Prizm software. Untreated cells were considered as negative control and normalized for $100 \%$.

\section{Genotoxic activity \\ The method of neutral Comet Assay}

The method of Comet Assay was performed under neutral conditions. CCL1 cells-control and treated with increasing concentrations of the tested NADES solvents and extracts for $24 \mathrm{~h}$ were mixed with $1.4 \%$ low-melting agarose and spread onto already pre-coated with $0.5 \%$ normal agarose microscopic slides. The microgels, covered with coverslips to assure equal distribution, were incubated at $4{ }^{\circ} \mathrm{C}$ for $10 \mathrm{~min}$. The coverslips were removed after solidification of the microgels. This was followed by a $20-\mathrm{min}$ incubation in a lysis buffer $(146 \mathrm{mM}$ $\mathrm{NaCl}, 30$ mM EDTA, pH 8; 10 mM Tris-HCl, pH 8; 0.1\% $\mathrm{N}$-lauroyl sarcosine). Incubation of the gels $3 \times 10 \mathrm{~min}$ in $0.5 \times \mathrm{TBE}$ buffer followed. Slides were electrophoresed in $0.5 \times \mathrm{TBE}$ buffer at $0.45 \mathrm{~V} / \mathrm{cm}$ for $20 \mathrm{~min}$. The slides were 
then dehydrated subsequently in $75 \%$ and $96 \%$ ethanol and left to fully dry at room temperature. The results were visualized under an epifluorescent microscope Leitz-Orthoplan, Vario Orthomat $2(450 / 490 \mathrm{~nm})$, after staining with SYBR Green (Roche Diagnostics GmbH). Treatment of CCL1 cells with $5 \mathrm{mM} \mathrm{H}_{2} \mathrm{O}_{2}$ for 30 min at $37{ }^{\circ} \mathrm{C}$ was performed as a positive control for genotoxicity. Results were analyzed by using the CometScore software. Three repetitions of the experiment have been done and data were evaluated using Excel 2016 software where values for the measured Olive Moment in all probes were presented as MEAN values \pm STDEV.

\section{FACS analysis for probing the cytostatic activity of the tested} solvents and extracts

CCL1 cells treated for $24 \mathrm{~h}$ with the NADES solvents and extracts were fixed in $100 \%$ ice-cold ethanol and stored at $-20{ }^{\circ} \mathrm{C}$ overnight. The cell pellets were washed twice with 1xPBS $\left(2.68 \mathrm{mM} \mathrm{KCl}, 1.47 \mathrm{mM} \mathrm{KH}_{2} \mathrm{PO}_{4}, 1.37 \mathrm{mM}\right.$ $\mathrm{NaCl}, 8 \mathrm{mM} \mathrm{Na}_{2} \mathrm{HPO}_{4}$ ), $\mathrm{pH}$ 7. Incubation with RNase A $(100 \mu \mathrm{g} / \mathrm{ml})$ for $30 \mathrm{~min}$ at $37{ }^{\circ} \mathrm{C}$ followed. Before FACS analysis the cells were stained with propidium iodide $(50 \mu \mathrm{g} / \mathrm{ml})$ for $20 \mathrm{~min}$ at dark. FACS analysis was performed by a BD FACSCanto apparatus and the results were analyzed by FlowJo software V10.

\section{Results and discussion}

Extraction and evaluation of extraction efficiency

Four NADES were selected based on literature data of their polarity, close or higher than $70 \%$ ethanol. They are described in Table 1, with corresponding abbreviations, and data of their density and polarity measured with the solvatochromic dye Nile red (lower $\mathrm{E}_{\mathrm{NR}}$ values mean higher polarity, [4].

The dry aerial parts of both selected plants were extracted with the four NADES and 70\% ethanol as a reference solvent. Ultrasound assisted extraction was applied to accelerate the process, because of the significant viscosity of the NADES. The NADES choline chloride-glucose 5:2 was too viscous and to enable mass transfer, water was added to make it suitable for extraction. It is known that addition of water decreases the viscosity of NADES and weakens the hydrogen bonding interaction between its components, but dilution under $50 \%$ usually does not lead to a matrix disruption into individual components [9].

The extraction yield was evaluated by measuring the total phenolics and total flavonoids in the extracts. Extraction with $70 \%$ ethanol under the same conditions was used as a reference. The results are presented in Table 2.

The results demonstrated that some of the NADES extracted more bioactive compounds than the classic water-alcohol mixture. The water-containing NADES $\mathrm{XXGlH}$ was the most effective one, it extracted more phenolics and more flavonoids from the mountain tea that $70 \%$ ethanol. In the case of plantain phenolics $\mathrm{XXGlH}$ was again the most effective solvent: it extracted $25 \%$ more phenolics, compared to the reference solvent. However, none of the four NADES extracted flavonoids from plantain more efficiently than the $70 \%$ ethanol. This difference could be explained considering the specific

Table 1 Composition and characteristics of the NADES

\begin{tabular}{lllllll}
\hline Abbreviation & Component $\mathbf{1}$ & Component 2 & Molar ratio & Water (\%) & $\mathbf{E}_{\mathbf{N R}}(\mathbf{k c a l} / \mathbf{m o l})$ & Density (g/ml) \\
\hline XXGly & Choline chloride & Glycerol & $1: 2$ & 0 & 50.03 & 1.17 \\
CAPD & Citric acid & 1,2-Propanediol & $1: 4$ & 0 & 48.87 & 1.19 \\
XXGIH & Choline chloride & Glucose & $5: 2$ & 30 & 49.17 & 1.16 \\
XXPD & Choline chloride & 1,2-Propanediol & $1: 3$ & 0 & 50.69 & 1.06 \\
EtOH 70\% & & & & 50.87 & 0.88 \\
\hline
\end{tabular}

Table 2 Amount of extracted plant constituents (percentage of dry plant material)

\begin{tabular}{|c|c|c|c|c|}
\hline \multirow[t]{2}{*}{ Extraction solvent } & \multicolumn{2}{|l|}{ S. scardica } & \multicolumn{2}{|l|}{ P. major } \\
\hline & Total phenolics, \% & Total flavonoids, \% & Total phenolics, \% & Total flavonoids, \% \\
\hline $70 \% \mathrm{EtOH}$ & $5.4 \pm 0.2$ & $1.14 \pm 0.02$ & $5.55 \pm 0.03$ & $1.11 \pm 0.06$ \\
\hline XXGly & $4.6 \pm 0.3$ & $1.02 \pm 0.03$ & $3.27 \pm 0.2$ & $0.51 \pm 0.06$ \\
\hline CAPD & $4.2 \pm 0.1$ & $0.87 \pm 0.03$ & $3.06 \pm 0.03$ & $0.69 \pm 0.06$ \\
\hline XXGIH & $6.3 \pm 0.2$ & $1.20 \pm 0.06$ & $6.99 \pm 0.5$ & $0.22 \pm 0.06$ \\
\hline XXPD & $5.6 \pm 0.2$ & $1.20 \pm 0.06$ & $4.62 \pm 0.2$ & $0.90 \pm 0$ \\
\hline
\end{tabular}


chemical structures of flavonoids in the two medicinal plants. In S. scardica, flavonoid diglycosides predominate [10], while the major flavonoids in P. major are flavone monoglycosides [11], which are less polar than diglycosides. As the chosen NADESs have polarities higher than $70 \%$ ethanol, the better extraction of more polar flavonoid diglycosides can be explained by this fact, at least to some extent.

\section{Antimicrobial activity}

Recently, it became clear that NADES components can be selected not only to fine-tune solvent physicochemical characteristics but also to improve the biological activity of dissolved active compounds [12,13]. That is why we decided to check the antimicrobial activity of the extracts, and to compare the results with the activity of ethanol extracts, based on total phenolics concentration. The minimum inhibitory concentrations (MIC) and minimum bactericidal concentrations $(\mathrm{MBC})$ of total phenolics in the extracts were measured. In addition, the metabolic activity of the microorganisms after the treatment was studied by measuring the dehydrogenase activity (DEHA) with the MTT test. The results of these tests are shown in Table 3.

The most potent antimicrobial activity was observed for CAPD/S against S. pyogenes, E. coli, S. aureus and C. albicans with MICs between 0.098 and $0.39 \mu \mathrm{g} / \mathrm{ml}$ total phenolics. CAPD/P was active against S. aureus, E. coli and C. albicans (MICs were in the range 1.99-3.98 $\mu \mathrm{g} / \mathrm{ml}$ total phenolics). The plantain extracts had $\mathrm{MBC}=\mathrm{MIC}$ for the three test microorganisms against which they were active. In this case the DEHA activity cannot be determined because it is equal to zero, as there are no metabolically active cells present. The extracts XXPD/S, $\mathrm{XXPD} / \mathrm{P}, \mathrm{XXGlH} / \mathrm{S}$, and XXGlH/P were inactive against the tested microorganisms. Surprisingly, the extracts with the NADES which was most effective in the extraction of phenolics and flavonoids, XXGlH, showed no antimicrobial activity. This could be due to qualitative differences between the extracts obtained with different

Table 3 MIC, MBC and dehydrogenase activity (MTT test) of total phenolics in different solvent extracts of S. scardica and P. major

\begin{tabular}{|c|c|c|c|c|c|c|}
\hline Sample/indicator & $\mathrm{XXGly/S^{ \textrm {a } }}$ & XXGly/Pb & CAPD/S $\mathrm{S}^{\mathrm{a}}$ & CAPD/Pb & $70 \%$ EtOH $/ \mathrm{S}$ & $70 \%$ EtOH/P \\
\hline \multicolumn{7}{|c|}{ S. pyogenes SAIM 10535} \\
\hline $\mathrm{MIC}(\mu \mathrm{g} / \mathrm{ml})$ & 380 & $N A^{c}$ & 0.19 & NA & $>67.5$ & $>69.3$ \\
\hline DEHA (\%) & - & NA & $39.88 \pm 9.6$ & NA & - & - \\
\hline $\mathrm{MBC}(\mu \mathrm{g} / \mathrm{ml})$ & 380 & NA & 1.56 & NA & $>67.5$ & $>69.3$ \\
\hline \multicolumn{7}{|l|}{ E. coli ATCC 35218} \\
\hline $\mathrm{MIC}(\mu \mathrm{g} / \mathrm{ml})$ & 47.5 & 38.75 & 0.39 & 3.984 & $>67.5$ & $>69.3$ \\
\hline DEHA (\%) & - & - & $1.31 \pm 0.87$ & - & - & - \\
\hline $\mathrm{MBC}(\mu \mathrm{g} / \mathrm{ml})$ & 47.5 & 38.75 & 0.78 & 3.984 & $>67.5$ & $>69.3$ \\
\hline \multicolumn{7}{|l|}{ S. aureus ATCC 29213} \\
\hline $\mathrm{MIC}(\mu \mathrm{g} / \mathrm{ml})$ & NA & NA & 0.098 & 1.99 & $>67.5$ & $>69.3$ \\
\hline DEHA (\%) & NA & NA & $9.8 \pm 2.3$ & - & - & - \\
\hline $\mathrm{MBC}(\mu \mathrm{g} / \mathrm{ml})$ & NA & NA & 0.39 & 1.99 & $>67.5$ & $>69.3$ \\
\hline \multicolumn{7}{|c|}{ P. aeruginosa ATCC 27853} \\
\hline $\mathrm{MIC}(\mu \mathrm{g} / \mathrm{ml})$ & 23.75 & 19.37 & NA & NA & $>67.5$ & $>69.3$ \\
\hline DEHA (\%) & - & - & NA & NA & - & - \\
\hline $\mathrm{MBC}(\mu \mathrm{g} / \mathrm{ml})$ & 23.75 & 19.37 & NA & NA & $>67.5$ & $>69.3$ \\
\hline \multicolumn{7}{|l|}{ C. albicans SAIM 562} \\
\hline MIC ( $\mu \mathrm{g} / \mathrm{ml})$ & 23.75 & 19.37 & 0.19 & 1.99 & $>67.5$ & $>69.3$ \\
\hline DEHA (\%) & - & - & $7.595 \pm 2.1$ & - & - & - \\
\hline $\mathrm{MBC}(\mu \mathrm{g} / \mathrm{ml})$ & 23.75 & 19.37 & 0.78 & 1.99 & $>67.5$ & $>69.3$ \\
\hline \multicolumn{7}{|l|}{ B. cereus ATCC 9634} \\
\hline $\mathrm{MIC}(\mu \mathrm{g} / \mathrm{ml})$ & 23.75 & 38.75 & NA & NA & $>67.5$ & $>69.3$ \\
\hline DEHA (\%) & $50 \pm 12.3$ & - & NA & NA & - & - \\
\hline $\mathrm{MBC}(\mu \mathrm{g} / \mathrm{ml})$ & 47.5 & 38.75 & NA & NA & $>67.5$ & $>69.3$ \\
\hline
\end{tabular}

Extracts with XXPD and XXGIH are inactive against all tested microorganisms

a Extract of $S$. scardica

b Extract of $P$. major

c NA: no activity. DEHA data are expressed as the mean \pm SD of three measurements 
solvents, however, qualitative analysis of the extracts was not performed. The present work aimed to find the most effective NADES for extraction of S. scardica and P. major in terms of antimicrobial potential. Optimization of the extraction conditions with the most effective solvent is the subject of future work, when we intend to apply more detailed analysis of individual constituents.

In most cases where antimicrobial activity was observed, it was much higher than the one of the traditional ethanol extracts. Such antimicrobial potentiating effects of NADESs was also observed in the case of propolis NADES extracts [14]. Although the addition of more than $50 \%$ of water to NADES during the antimicrobial tests breaks the NADES supramolecular complex, the individual NADES constituents could contribute to the overall effect of the solution [15] and some synergistic effects are also to be considered. Especially in the case of the CAPD extract of $S$. scardica, the increased effect compared to the other extracts can be partly explained by the effect of the presence of citric acid as an element of the NADES. In the literature there are indications that NADES containing organic acids possess higher antimicrobial activity, since some organic acids present many pharmacological effects [16].

\section{Genotoxicity and cytotoxicity}

Any further implication of the tested four NADES in the practice requires proofs for their genotoxicity safety. Many data in the literature show the genotoxicity of a broad range of food, cosmetic and pharmaceutical additives regardless of their nature [17-19]. Some data point to the fact that these substances added to the products consumed by or applied on people exert their genotoxicity at allowed concentrations [17, 20, 21]. This unambiguously entails the application of sensitive tests for fast and accurate evaluation of the potential of any substance that is planned to be implicated in food, pharmaceutical and cosmetic practices to induce general cytotoxicity via inhibiting cell proliferation and/or damage in DNA [22-24]. The method of Comet Assay is a brilliant technology for fast and sensitive analysis of genotoxicity [25, 26]; it requires single cells, is fast and with high precision evaluates all kinds of DNA damages. Data quantification allows precise estimation of genotoxicity. In this study, the tested NADES solvents and the extracts which demonstrated antimicrobial activity: the extracts with XXGly and CAPD of S. scardica and P. major, were tested for their genotoxicity. The preparation for this test first required the evaluation of the in vitro cytotoxicity of the tested substances. Therefore, the in vitro cytotoxicity of the NADESs and extracts was determined on the normal mouse fibroblast cell line CCL-1 (Table 4) for two exposure times -24 and $72 \mathrm{~h}$. The $\mathrm{IC}_{50}$ values calculated after
$24 \mathrm{~h}$ exposure time were used for performing the genotoxicity assay. The calculated $\mathrm{IC}_{50}$ concentrations of all tested samples are given in Table 4.

As visible from the median inhibitory concentrations in Table 4, the solvent XXGly was less cytotoxic than CAPD. The same trend was observed for the relevant extracts. Interestingly, the cytotoxicity of the solvents XXGly, CAPD and XXGIH diminished with time and was less pronounced after $72 \mathrm{~h}$ of exposure than after $24 \mathrm{~h}$. All extracts showed dose and time dependent cytotoxicity. The XXGly/S extract exhibited more potent antiproliferative effect on mouse fibroblasts than $\mathrm{XXGly} / P$ and was more cytotoxic to the cells than the solvent itself in both exposure periods. The cytotoxicity of XXGly/P was more pronounced than that of the solvent after the longer exposure period (72 h). CAPD/S showed a twofold higher antiproliferative effect on the cells after $24 \mathrm{~h}$ of exposure than CAPD. However, after $72 \mathrm{~h}$ the effect of $C A P D / S$ diminished slightly compared to that of the solvent at the first incubation period. The cytotoxicity of the CAPD/P extract was time-dependent and the $\mathrm{IC}_{50}$ values were significantly lower than those of the pure solvent, especially after long exposure time. Considering the MIC values determined by the BMD assay, it can be seen that $C A P D / P$ exhibited anti-staphylococcal and antifungal activities at concentrations 3.9 and $1.99 \mu \mathrm{g} / \mathrm{ml} \mathrm{tP}$, respectively, that are significantly lower than the median inhibitory concentration cytotoxic for normal mouse fibroblasts $\left(\mathrm{IC}_{50} / 24 \mathrm{~h}=4.6 \mu \mathrm{g} / \mathrm{ml} \mathrm{tP}\right)$.

After estimation of the cytotoxicity of the studied NADES solvents and extracts, CCL1 cells were subjected to Comet assay. CCL1 cells were treated with the four tested NADES and extracts of $S$. scardica and $P$. major with XXGly and CAPD, for $24 \mathrm{~h}$ at optimal conditions. Both the pure NADES and the NADES extracts were applied to the monolayer cells at concentrations of $\mathrm{IC}_{50}, 1 / 2 \mathrm{IC}_{50}$ and $1 / 4 \mathrm{IC}_{50}$, estimated by MTT tests (Table 4). Untreated cells were used as negative control while CCL1 cells treated for $30 \mathrm{~min}$ at $37^{\circ} \mathrm{C}$ with $5 \mathrm{mM} \mathrm{H}_{2} \mathrm{O}_{2}$ were used as a positive control for genotoxicity.

The Comet Assay results were quantified with the CometScore software and the values for the Olive Moment are presented in Fig. 1. Results demonstrated that all NADESs at a concentration of $\mathrm{IC}_{50}$ showed moderate to subtle genotoxicity effect except XXGly that at a concentration of $\mathrm{IC}_{50}$ demonstrated the highest genotoxic potential in comparison to all other solvents applied at $\mathrm{IC}_{50}$. Dilution two and four times of the applied $\mathrm{IC}_{50}$ of all solvents showed lack of genotoxic potential on the tested CCL1 cells. The less genotoxic were all tested concentrations of CAPD (Fig. 1a). Further, extracts of S. scardica and $P$. major with XXGly and CAPD were tested for genotoxicity with the method of Comet Assay and results are 
Table 4 Calculated IC 50 values for the tested four NADES solvents and the extractss from S. scardica and $P$. major

\begin{tabular}{|c|c|c|c|c|c|c|}
\hline \multirow[t]{3}{*}{ Tested samples } & \multicolumn{6}{|c|}{ Median inhibitory concentrations, parameters of the model and exposure time } \\
\hline & \multicolumn{3}{|l|}{$24 \mathrm{~h}$} & \multicolumn{3}{|l|}{$72 \mathrm{~h}$} \\
\hline & $\mathrm{IC}_{50}^{\mathrm{a}}(\% \mathrm{v} / \mathrm{v}, \mu \mathrm{I})$ & $95 \% \mathrm{Cl}^{\mathrm{b}}$ & $\mathbf{R}$ & $\mathrm{IC}_{50}(\% \mathrm{v} / \mathrm{v}, \mu \mathrm{I})$ & $95 \% \mathrm{Cl}$ & $\mathrm{R}^{\mathrm{c}}$ \\
\hline \multicolumn{7}{|l|}{ Solvents } \\
\hline XXGly & 1.180 & $0.985-1.412$ & 0.904 & 1.394 & $1.261-1.542$ & 0.950 \\
\hline CAPD & 0.089 & $0.075-0.105$ & 0.940 & 0.141 & $0.126-0.158$ & 0.971 \\
\hline$X X G H$ & 0.077 & $0.043-0.139$ & 0.980 & 0.096 & $0.085-0.108$ & 0.964 \\
\hline XXPD & 2.677 & $1.516-4.611$ & 0.906 & 1.503 & $1.197-1.887$ & 0.707 \\
\hline \multicolumn{7}{|l|}{ Extracts } \\
\hline XXGly/S & 0.803 & $0.563-1.148$ & 0.952 & 0.589 & $0.391-0.886$ & 0.901 \\
\hline XXGly/P & 1.267 & $0.957-1.679$ & 0.912 & 1.094 & $0.845-1.418$ & 0.894 \\
\hline CAPD/S & 0.046 & $0.040-0.054$ & 0.955 & 0.148 & $0.136-0.161$ & 0.971 \\
\hline \multirow[t]{2}{*}{ CAPD/P } & 0.045 & $0.039-0.053$ & 0.956 & 0.024 & $0.021-0.027$ & 0.962 \\
\hline & $I C_{50}\left(\mu \mathrm{g} / \mathrm{ml} \mathrm{tP^{d }}\right)$ & $95 \% \mathrm{Cl}$ & $\mathbf{R}$ & $\mathrm{IC}_{50}(\mu \mathrm{g} / \mathrm{ml} \mathrm{tP})$ & $95 \% \mathrm{Cl}$ & $\mathbf{R}$ \\
\hline \multicolumn{7}{|l|}{ Extracts } \\
\hline XXGly/S & 12.212 & $8.550-17.450$ & 0.952 & 8.953 & $5.941-13.490$ & 0.901 \\
\hline XXGly/P & 15.711 & 11.863-20.820 & 0.912 & 13.566 & $10.470-17.590$ & 0.894 \\
\hline CAPD/S & 0.046 & $0.040-0.054$ & 0.955 & 0.148 & $0.136-0.161$ & 0.971 \\
\hline CAPD/P & 4.607 & $4.026-5.376$ & 0.956 & 0.243 & $0.210-0.275$ & 0.962 \\
\hline
\end{tabular}

shown in Fig. 1b. All extracts applied at concentration of $\mathrm{IC}_{50}$ demonstrated genotoxicity on CCL1 cells, especially CAPD/S. Specifically, XXGly/S and XXGly/P, CAPD/S and $\mathrm{CAPD} / \mathrm{P}$ showed a decrease in the detected genotoxicity when applied at $1 / 2$ and $1 / 4$ of $\mathrm{IC}_{50}$. The most harmless was $\mathrm{CAPD} / \mathrm{P}$.

These NADES probes demonstrated a lack of genotoxicity at all tested concentrations. Conserning the detected genotoxicity the NADES solvents can be classified in a row showing an increase in genotoxicity with an increase in the tested concentrations of the compounds. The NADES solvents and extracts are listed in the direction left to right, which marks increased genotoxicity. The NADES solvents are arranged as follows: $\mathrm{CAPD}<\mathrm{XXGIH}<\mathrm{XXPD}<\mathrm{XXGly}$. The extracts can be classified like this: $\mathrm{CAPD} / \mathrm{P}<\mathrm{XXGly} / \mathrm{P}<\mathrm{XXGly} / \mathrm{S}<\mathrm{CAP}$ $\mathrm{D} / \mathrm{S}$.

Generally, all tested NADES revealed little changes in the distribution of cells in the different phases of the cell cycle after treatment for $24 \mathrm{~h}$ with increasing concentrations. The closer look at the graph in Fig. 2a shows that $\mathrm{XXGIH}$ at all tested concentrations, most explicitly at $1 / 2$ and $1 / 4 \mathrm{IC}_{50}$ demonstrated decrease in the population of cells in G0/G1, suggesting a slight cytostatic effect. CCL1 cells treated with $\mathrm{CAPD} / \mathrm{S}$ applied at $\mathrm{IC}_{50}$, and $\mathrm{CAPD} / \mathrm{P}$ at all tested concentrations, especially at $1 / 4 \mathrm{IC}_{50}$ showed fewer cells in G0/G1. These results correspond with the detected genotoxicity in the samples. The detected genotoxicity led to moderate cytostatic effect on the CCL1 cells.

All tested NADES proved harmless genome integrity of the tested CCL1 cells. The detected little changes in the percentage of cells in different phases of the cell cycle can be due to cell culture asynchronization.

\section{Conclusions}

In conclusion, our results confirm the promising potential of NADESs as solvents for extraction of the biologically active constituents of popular medicinal plants and confirm the suggestion that NADES can improve the biological effects of bioactive extracts [12]. Best extraction results for total phenolics for the studied plants were obtained using XXGlH, but surprisingly these extracts were inactive against all tested microorganisms and were not subjected to further studies of in vitro cytotoxic and genotoxic activity. The most effective were the extracts with CAPD. The presence of citric acid and some synergistic effects with Sideritis constituents may play a role, as CAPD extract of $S$. scardica was much more active compared to the respective $P$. major extract. 


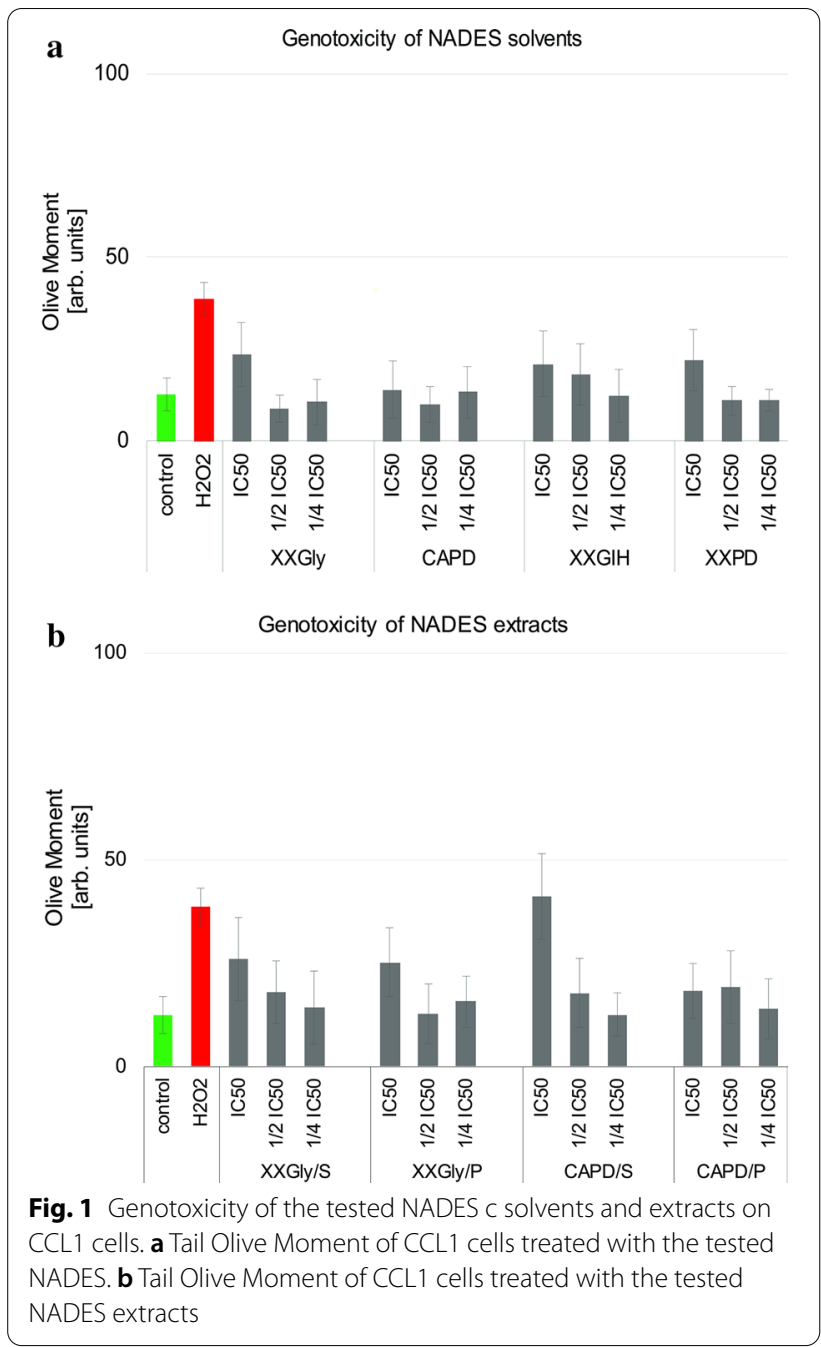

The use of NADESs allows avoiding organic solvents and the significant antimicrobial potential of the NADES extracts combined with the low toxicity and genotoxicity of the solvents and the extracts present a very promising perspective for using these extracts in food, cosmetic and pharmaceutical formulations. Of course, further studies are needed to answer the question of the influence of the NADES on the bioactivity of the dissolved substances, and to elucidate the fine molecular mechanisms of their action in model cells and organisms.

\section{Abbreviations}

ATCC: American Type Cell Culture Collection; BHIB: Brain Heart Infusion Broth BHIA: Brain Heart Infusion Agar; CAPD: Citric acid-1,2-propanediol 1:4; DEHA: Dehydrogenase activity; DES: Deep eutectic solvent(s); FACS: Fluorescence activated cell sorting; MBC: Minimum bactericidal concentration; MHA: Muller Hinton Agar; MHB: Muller Hinton Broth; MIC: Minimum inhibitory concentration; MTT: 3-(4,5-Dimethylthiazol-2-yl)-2,5-diphenyltetrazolium bromide; NADES: Natural deep eutectic solvent(s); tP: Total phenolics; XXGIH: Choline chloride-glucose 5:2 and 30\% water; XXGly: Choline chloride-glycerol 1:2;

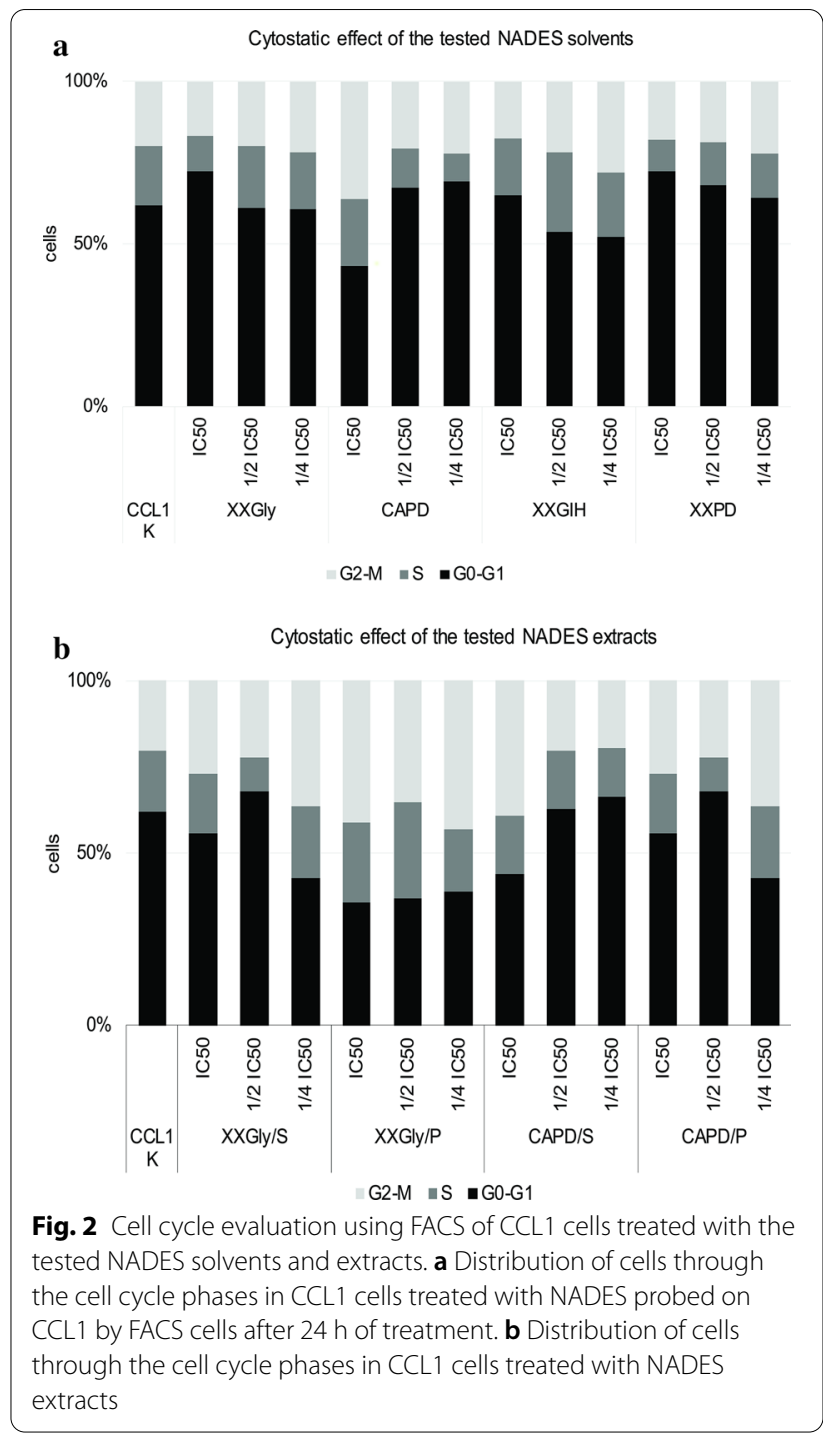

XXPD: Choline chloride-1,2-propanediol 1:3; /P: Extract of Plantago major; /S: Extract of Sideritis scardica.

\section{Authors' contributions}

VB conceived the study and was in charge of overall direction and planning, TG, BT, MP and KA performed chemical experiments: preparation of NADES, extractions, chemical analyses; LD and MMZ performed the antimicrobial assays, measured the dehydrogenase activity and participated in the data analysis, MMZ and YI performed cytotoxicity test, $\mathrm{HN}$ directed the design of microbiological tests and the analysis of the data; $M G, G M, B V$ performed genotoxicity tests and data analysis; VN, HN and MG drafted the manuscript. All authors read and approved the final manuscript.

\section{Funding}

This work was supported by the Bulgarian National Science Fund (Grant DH 19/4).

\section{Availability of data and materials}

All materials used in the present study are mentioned in "Materials and methods"section and the data will be available upon request. 


\section{Competing interests}

The authors declare that they have no competing interests.

\section{Author details}

${ }^{1}$ Institute of Organic Chemistry With Centre of Phytochemistry, Bulgarian Academy of Sciences, Acad. G. Bonchev Str., BI. 9, 1113 Sofia, Bulgaria. ${ }^{2}$ The Stephan Angeloff Institute of Microbiology, Bulgarian Academy of Sciences, Acad. G. Bonchev Str., BI. 26, 1113 Sofia, Bulgaria. ${ }^{3}$ Institute of Molecular Biology "Roumen Tsanev", Bulgarian Academy of Sciences, Acad. G. Bonchev Str., BI. 21, 1113 Sofia, Bulgaria.

Received: 7 July 2020 Accepted: 4 December 2020

Published online: 11 December 2020

\section{References}

1. Dai Y, van Spronsen J, Witkamp GJ, Verpoorte R, Choi YH (2013) Natural deep eutectic solvents as new potential media for green technology. Anal Chim Acta 766:61-68

2. Jeong KM, Ko J, Zhao J, Jin Y, Han SY, Lee J (2017) Multi-functioning deep eutectic solvents as extraction and storage media for bioactive natural products that are readily applicable to cosmetic products. J Clean Prod 151:87-95

3. Ruesgas-Ramón M, Figueroa-Espinoza MC, Durand E (2017) Application of deep eutectic solvents (DES) for phenolic compounds extraction: overview, challenges, and opportunities. J Agric Food Chem 65(18):3591-3601

4. Ogihara W, Aoyama T, Ohno H (2004) Polarity measurement for ionic liquids containing dissociable protons. Chem Lett 33(11):1414-1415

5. Espino M, de los Ángeles Fernández M, Gomez FJ, Silva MF (2016) Natural designer solvents for greening analytical chemistry. TrAC Trends Analyt Chem 76:126-136

6. Dimitrova L, Zaharieva MM, Popova M, Kostadinova N, Tsvetkova I, Bankova V, Najdenski H (2017) Antimicrobial and antioxidant potential of different solvent extracts of the medicinal plant Geum urbanum L. Chem Cent J 11:113

7. Mosmann T (1983) Rapid colorimetric assay for cellular growth and survival: application to proliferation and cytotoxicity assays. J Immunol Methods 65(1-2):55-63

8. ISO 10993-5:2009 (2017) Biological evaluation of medical devices_Part 5: tests for in vitro cytotoxicity, in ICS 11.100.20. International Organization for Standardization. https://www.iso.org/standard/36406.html.

9. Dai Y, Witkamp GJ, Verpoorte R, Choi YH (2015) Tailoring properties of natural deep eutectic solvents with water to facilitate their applications. Food chem 187:14-19

10. Todorova M, Trendafilova A (2014) Sideritis scardica Griseb., an endemic species of Balkan peninsula: traditional uses, cultivation, chemical composition, biological activity. J Ethnopharmacol 152(2):256-265

11. Samuelsen $A B(2000)$ The traditional uses, chemical constituents and biological activities of Plantago major L. A review. J Ethnopharmacol 71(1-2):1-21

12. Murador DC, de Souza Mesquita LM, Vannuchi N, Braga ARC, de Rosso V (2019) Bioavailability and biological effects of bioactive compounds extracted with natural deep eutectic solvents and ionic liquids: advantages over conventional organic solvents. Cur Opin Food Sci 26:25-34

13. Wikene KO, Rukke HV, Bruzell E, Tønnesen HH (2017) Investigation of the antimicrobial effect of natural deep eutectic solvents (NADES) as solvents in antimicrobial photodynamic therapy. J Photochem Photobiol B 171:27-33

14. Trusheva B, Petkov H, Popova M, Dimitrova L, Zaharieva M, Tsvetkova I, Najdenski H, Bankova V (2019) "Green" approach to propolis extraction: natural deep eutectic solvents. C R Acad Bulg 72(7):897-905

15. Gutiérrez MC, Ferrer ML, Mateo CR, del Monte F (2009) Freeze-drying of aqueous solutions of deep eutectic solvents: a suitable approach to deep eutectic suspensions of self-assembled structures. Langmuir 25(10):5509-5515

16. Radošević K, Čanak I, Panić M, Markov K, Bubalo MC, Frece J, Srček VG, Redovniković IR (2018) Antimicrobial, cytotoxic and antioxidative evaluation of natural deep eutectic solvents. Environ Sci Pollut Res 25(14):14188-14196

17. Eliaz I, Weil E, Schwarzbach J, Wilk B (2019) Modified citrus pectin/alginate dietary supplement increased fecal excretion of ranium: a family. Altern Ther Health Med 25(4):20-24

18. Peycheva E, Alexandrova R, Miloshev G (2014) Application of the yeast comet assay in testing of food additives for genotoxicity. LWT Food Sci Technol 59(1):510-517

19. Tice RR, Agurell E, Anderson D, Burlinson B, Hartmann A, Kobayashi H, Miyamae Y, Rojas E, Ryu JC, Sasaki YF (2000) Single cell gel/comet assay: guidelines for in vitro and in vivo genetic toxicology testing. Environ Mol Mutagen 35(3):206-221

20. Bilal M, lqbal HMN (2019) An insight into toxicity and human-healthrelated adverse consequences of cosmeceuticals - a review. Sci Total Environ 670:555-568

21. Draganova-Filipova M, Mourdjeva M, Popova Z, Peycheva E, Miloshev G, Sarafian V (2009) Propolis induced apoptosis in MC Coy-Plovdiv Cells. Biotechnol Biotechnol Equip 23(sup1):635-638

22. Bajpayee M, Kumar A, Dhawan A (2013) The comet assay: assessment of in vitro and in vivo DNA damage. In: Dhawan A, Bajpayee M (eds) Genotoxicity assessment. Humana, New York, pp 237-257

23. Collins AR (2015) The comet assay: a heavenly method! Mutagenesis 30(1):1-4

24. Staneva D, Peycheva E, Georgieva M, Efremov T, Miloshev G (2013) Application of comet assay for the assessment of DNA damage caused by chemical genotoxins in the dairy yeast Kluyveromyces lactis. Antonie Van Leeuwenhoek 103(1):143-152

25. Fairbairn DW, Olive PL, O'Neill KL (1995) The comet assay: a comprehensive review. Mutat Res 339(1):37-59

26. Peycheva E, Georgieva M, Miloshev G (2009) Comparison between alkaline and neutral variants of yeast comet assay. Biotechnol Biotechnol Equip 23(1):1090-1092

\section{Publisher's Note}

Springer Nature remains neutral with regard to jurisdictional claims in published maps and institutional affiliations.

Ready to submit your research? Choose BMC and benefit from

- fast, convenient online submission

- thorough peer review by experienced researchers in your field

- rapid publication on acceptance

- support for research data, including large and complex data types

- gold Open Access which fosters wider collaboration and increased citations

- maximum visibility for your research: over 100M website views per year

At $\mathrm{BMC}$, research is always in progress.

Learn more biomedcentral.com/submissions 